\title{
Undernutrition reduces kisspeptin and neurokinin B expression in castrated male sheep
}

\author{
Christina M Merkley, Allison N Renwick, Sydney L Shuping, KaLynn Harlow, Jeffrey R Sommer and Casey C Nestor \\ Department of Animal Science, North Carolina State University, Raleigh, North Carolina, USA \\ Correspondence should be addressed to C C Nestor; Email: ccnestor@ncsu.edu
}

\begin{abstract}
Undernutrition impairs reproductive success through suppression of gonadotropin-releasing hormone (GnRH), and subsequently luteinizing hormone (LH), secretion. Given that kisspeptin and neurokinin B (NKB) neurons in the arcuate nucleus (ARC) of the hypothalamus are thought to play key stimulatory roles in the generation of GnRH/LH pulses, we hypothesized that feed restriction would reduce the ARC mRNA abundance and protein expression of kisspeptin and NKB in young, male sheep. Fourteen wethers (castrated male sheep five months of age) were either fed to maintain (FM; $n=6$ ) pre-study body weight or feed-restricted (FR; $n=8)$ to lose $20 \%$ of pre-study body weight over 13 weeks. Throughout the study, weekly blood samples were collected and assessed for LH concentration using RIA. At Week 13 of the experiment, animals were killed, heads were perfused with $4 \%$ paraformaldehyde, and brain tissue containing the hypothalamus was collected, sectioned, and processed for detection of mRNA (RNAscope) and protein (immunohistochemistry) for kisspeptin and NKB. Mean LH was significantly lower and LH inter-pulse interval was significantly higher in FR wethers compared to FM wethers at the end of the experiment (Week 13). RNAscope analysis revealed significantly fewer cells expressing mRNA for kisspeptin and NKB in FR wethers compared to FM controls, and immunohistochemical analysis revealed significantly fewer immunopositive kisspeptin and NKB cells in FR wethers compared to FM wethers. Taken together, this data supports the idea that long-term feed restriction regulates $\mathrm{GnRH} / \mathrm{LH}$ secretion through central suppression of kisspeptin and NKB in male sheep.
\end{abstract}

\section{Lay summary}

While undernutrition is known to impair reproduction at the level of the brain, the components responsible for this in the brain remain to be fully understood. Using male sheep we examined the effect of undernutrition on two stimulatory molecules in the brain critical for reproduction: kisspeptin and neurokinin B. Feed restriction for several weeks resulted in decreased luteinizing hormone in the blood indicating reproductive function was suppressed. In addition, undernutrition also reduced both kisspeptin and neurokinin $B$ levels within a region of the brain involved in reproduction, the hypothalamus. Given that they have stimulatory roles in reproduction, we believe that undernutrition acts in the brain to reduce kisspeptin and neurokinin $B$ levels leading to the reduction in luteinizing hormone secretion. In summary, longterm undernutrition inhibits reproductive function in sheep through suppression of kisspeptin and neurokinin B within the brain.

Key Words: $\triangleright$ kisspeptin $\gg$ neurokinin $\mathrm{B} \quad$ sheep $\quad$ undernutrition $\quad$ LH 


\section{Introduction}

The capacity for reproduction first occurs at puberty and is the result of an activated hypothalamicpituitary-gonadal axis. As a critical window of time in physiological development, puberty onset is heralded at the neuroendocrine level by an elevation of pulsatile gonadotropin-releasing hormone $(\mathrm{GnRH})$ secretion from the CNS, which in turn elicits an increase of luteinizing hormone (LH) secretion from the anterior pituitary. It has been known for decades that undernutrition delays puberty onset in mammals (Glass \& Swerdloff 1980, Chakravarty et al. 1982, Fitzgerald et al. 1982, Foster \& Olster 1985, Day et al. 1986) and with evidence that insufficient energy intake (caloric restriction) reduces GnRH release into the hypophyseal portal circulation (I'Anson et al. 2000), there is a central mechanism whereby undernutrition impairs reproduction through a reduction in GnRH/ LH secretion. Given that direct nutritional regulation of GnRH neurons is unlikely as they are devoid of leptin and insulin receptors (Finn et al. 1998, Hakansson et al. 1998, Quennell et al. 2009, Louis et al. 2011, Cernea et al. 2016), the central mechanism whereby undernutrition regulates $\mathrm{GnRH} / \mathrm{LH}$ secretion is likely mediated by afferent input to GnRH neurons.

Mutations in the genes encoding the neuropeptide kisspeptin or its receptor, Kiss1R (also known as G-protein coupled receptor 54, GPR54) result in impairment of pubertal maturation and reproductive function in humans and mice (de Roux et al. 2003, Seminara et al. 2003, Topaloglu et al. 2012), which is compelling evidence that kisspeptin is an essential component of normal pubertal development and fertility. With nearly all GnRH neurons expressing Kiss1R (Irwig et al. 2004, Herbison et al. 2010, Smith et al. 2011, Bosch et al. 2013) and the robust stimulatory actions of kisspeptin on GnRH and gonadotropin release in numerous mammalian species (Irwig et al. 2004, Navarro et al. 2004, Shahab et al. 2005, Mason et al. 2007, Lents et al. 2008, Jayasena et al. 2009, Magee et al. 2009, Ohkura et al. 2009), kisspeptin is believed to provide the direct stimulatory drive to $\mathrm{GnRH}$ neurons. Similar to kisspeptin, neurokinin B (NKB) is also essential for puberty, as loss-of-function mutations in the genes encoding NKB or its receptor, neurokinin 3 receptor (NK3R), result in failure of pubertal progression and infertility in humans (Topaloglu et al. 2009). Furthermore, administration of NKB or senktide (an NK3R receptor agonist) has been shown to stimulate LH secretion in multiple species (Billings et al. 2010, Ramaswamy et al. 2010, Wakabayashi et al. 2010, Navarro et al. 2011, Nestor et al. 2012). Since kisspeptin neurons in the arcuate nucleus (ARC) of the hypothalamus highly express NK3R, while GnRH neurons appear to be devoid of NK3R (Amstalden et al. 2010, Ahn et al. 2015), NKB action is thought to occur through stimulation of ARC kisspeptin which in turn stimulates GnRH neurons. In support of this, work in rodents has shown that removal of Kiss1R signaling abrogates the response to senktide (Garcia-Galiano et al. 2012, Grachev et al. 2012b) and thus demonstrates that NKB signaling is upstream of kisspeptin signaling.

Given their dominant stimulatory roles in reproduction, kisspeptin and NKB may also play an important part in mediating the effect of undernutrition on GnRH/LH secretion. Unlike GnRH neurons, ARC kisspeptin appear to express receptors for both leptin (Smith et al. 2006, Backholer et al. 2010b, Cravo et al. 2011) and insulin (Cernea et al. 2016), and thus may be a direct target of these key metabolic hormones. In addition, food deprivation (total food withdrawal for $48-72 \mathrm{~h}$ ) has been shown to reduce hypothalamic mRNA abundance of kisspeptin (Castellano et al. 2005, True et al. 2011, Navarro et al. 2012) and protein expression of kisspeptin in the ARC (Polkowska et al. 2015). Furthermore, while shortterm feed restriction (30\% feed withdrawal for 10 days) in pigs elicit no change in mRNA for kisspeptin and increases mRNA for NKB (Thorson et al. 2018), others have shown in mice, rats, and sheep that long-term food restriction (30-60\% food withdrawal for several weeks/months) is capable of reducing ARC mRNA abundance of kisspeptin (Backholer et al. 2010a, True et al. 2011, Yang et al. 2016) and NKB (True et al. 2011, Yang et al. 2016). While this evidence provides valuable insight into the central link between energy balance and reproduction, data on the effects of undernutrition on kisspeptin and NKB in males is limited, and thus far has only been reported for food deprivation in mice (Castellano et al. 2005). Moreover, previous reports have focused on how undernutrition impacts either mRNA or protein but have yet to report both message and protein within an experiment. Therefore, in the present study, we used a chronic feed restriction model to examine the effects of undernutrition on mRNA and protein for kisspeptin and NKB in the ARC of young, castrated male sheep (wethers). The use of wethers in these experiments enabled us to examine direct nutritional effects on LH secretion independent of changes in sensitivity to gonadal steroid feedback that may result from undernutrition. We hypothesized that chronic feed restriction, which would suppress LH secretion, would reduce both mRNA abundance and protein expression of kisspeptin and NKB. To test this 
hypothesis, we used a relatively new fluorescent in situ hybridization technique, RNAscope, to assess mRNA and classic immunohistochemistry for protein detection.

\section{Materials and methods}

\section{Animals}

Fourteen Suffolk wethers (male sheep castrated between four and six weeks of age) were approximately five months of age at the start of the study which was conducted from July through October. Prior to the study, wethers were housed in an open barn for a minimum of 14 days, and received open access to water and hay supplemented with the experimental diet (crude protein 12\%, crude fat $2.5 \%$, crude fiber 5.0\%; Mule City Specialty Feeds, Benson, $\mathrm{NC})$. Once moved indoors for the duration of the study, all sheep were housed individually, provided with water ad libitum and fed once daily with the experimental diet. Indoor lighting simulated changes in natural day length throughout the study. Blood samples were obtained using jugular venipuncture, collected into heparinized tubes, and plasma was stored at $-20^{\circ} \mathrm{C}$. All procedures were approved by the North Carolina State University Animal Care and Use Committee and followed the National Institutes of Health guidelines for use of animals in research.

\section{Experimental design}

The experimental design for this study is depicted in Fig. 1A. Briefly, 14 wethers were divided into one of two groups: fed to maintain body weight (FM; $n=6$ ) or feedrestricted to lose body weight (FR; $n=8$ ). Based on previous reports in sheep (Foster \& Olster 1985, Adam et al. 1997, McManus et al. 2005), each animal in the FM group was fed the experimental diet in order to maintain their prestudy body weight, while each animal in the FR group was fed less of the same diet in order to lose $20 \%$ of their own pre-study body weight over the course of 13 weeks. Body weight data were collected weekly throughout the experiment, and feed intake for each group was adjusted to produce the desired change in weight. Peripheral blood samples were collected weekly (from Weeks 0 to 13 ) via jugular venipuncture every $12 \mathrm{~min}$ for $4.5 \mathrm{~h}$.

\section{Tissue collection}

Tissue was collected as previously described (Foradori et al. 2006). Briefly, at the end of the experiment (Week $13)$, all wethers were heparinized $(20,000 \mathrm{U}$, intravenous) and killed with an intravenous overdose of sodium pentobarbital (Euthasol; Patterson Veterinary, Greeley, $\mathrm{CO})$. Heads were removed and perfused via the carotid arteries with four liters of $4 \%$ paraformaldehyde (PFA) in $0.1 \mathrm{M}$ PBS (pH 7.4) containing $0.1 \%$ sodium nitrite. Blocks of tissue containing the hypothalamus were removed and stored in $4 \%$ PFA for $24 \mathrm{~h}$ at $4{ }^{\circ} \mathrm{C}$ and transferred to a $20 \%$ sucrose solution until sectioning. Frozen coronal sections were cut at $50 \mu \mathrm{m}$ with a freezing microtome into five parallel series and stored in cryopreservative solution until used for RNAscope and immunohistochemistry.

\section{RNA scope in situ hybridization}

For the detection of mRNA for kisspeptin and NKB, RNAscope was performed on PFA-fixed hemisections from FM and FR wethers mounted on Superfrost/Plus microscope slides (Fisher Scientific). Three sections in the middle ARC were selected in each animal from a series of every fifth hypothalamic section $(250 \mu \mathrm{m}$ apart), with the middle ARC defined as the level of the tuberoinfundibular sulcus until the beginning of the formation of the mammillary recess of the third ventricle (Merkley et al. 2012, Weems et al. 2016). Each full coronal section was cut at midline with only one side of the tissue

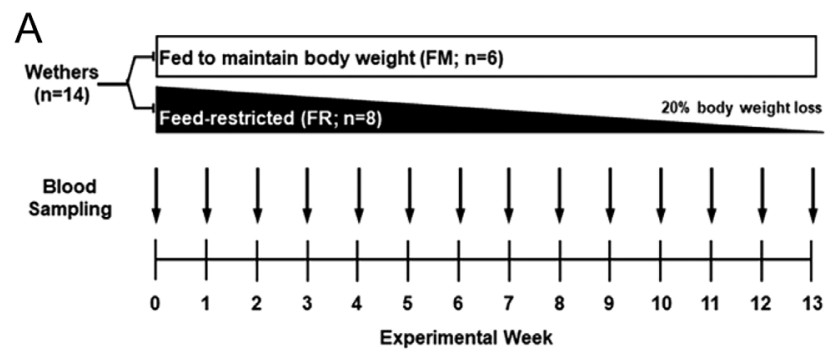

B

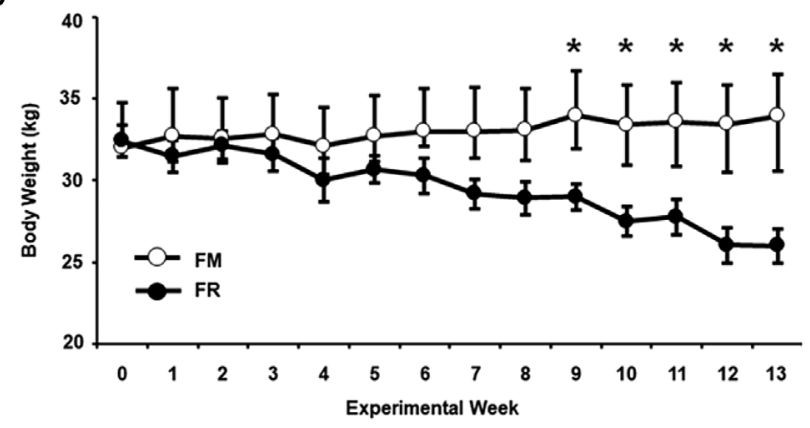

Figure 1 (A) At Week 0 , wethers were divided into fed to maintain body weight (FM; $n=6)$ and feed-restricted to lose body weight (FR; $n,=8)$ groups. Weekly blood sampling was conducted from the start of the experiment (Week 0) through the end of the study (Week 13). (B) From Week 9 to Week 13, average body weights (mean \pm S.E.M.) were significantly lower in FR wethers compared to FM wethers $(* P<0.05)$. 
section used for RNAscope. In situ hybridization was performed based on instructions from Advanced Cell Diagnostics and technical recommendations with minor modifications using the RNAscope Multiplex Fluorescent Reagent Kit v2 (Advanced Cell Diagnostics, Newark, CA; cat\# 323100). All incubations between 40 and $60^{\circ} \mathrm{C}$ were conducted using an ACD HybEZ II Hybridization System with EZ-Batch Slide System (Advanced Cell Diagnostics; cat\# 321710). On day 1, hemisections were washed overnight in $0.1 \mathrm{M}$ PBS at $4^{\circ} \mathrm{C}$ on a rocking shaker to remove excess cryoprotectant. On day 2 , hemisections were mounted onto microscope slides and allowed to dry for $2 \mathrm{~h}$. Then slides with sections were heated at $60^{\circ} \mathrm{C}$ for $90 \mathrm{~min}$, submerged in chilled $4 \%$ PFA at $4^{\circ} \mathrm{C}$ for $1 \mathrm{~h}$, and rinsed four times in $0.1 \mathrm{M}$ PBS ( $5 \mathrm{~min} /$ rinse). Slides were then incubated in increasing concentrations of ethanol $(50,70,100$, and $100 \%)$ for $5 \mathrm{~min}$ at each concentration. Slides were then allowed to dry at room temperature (RT) for 5 min and then incubated in Hydrogen Peroxide solution (10 min at RT; Advanced Cell Diagnostics, cat\# 322335). Next, slides were briefly rinsed with deionized water five times, treated with Target Retrieval solution (15 min at $100^{\circ} \mathrm{C}$; Advanced Cell Diagnostics, cat\# 322001), then rinsed in deionized water five times followed by quick submersion in $100 \%$ ethanol five times and allowed to air dry. A hydrophobic barrier was then created around the tissue using an ImmEdge Pen (Advanced Cell Diagnostics; cat\# 310018), and slides were stored overnight at $4^{\circ} \mathrm{C}$. On day 3 , sections were treated with RNAscope ${ }^{\circledR}$ Protease III $\left(30 \mathrm{~min}\right.$ at $40^{\circ} \mathrm{C}$; Advanced Cell Diagnostics, cat\# 322337), and subsequently incubated with RNAscope target (kisspeptin, Oa-KISS1-C3, cat\# 497471-C3; NKB, Oa-TAC3-O1, cat\# 481411) and control probes (positive controls, Oa-UBC-C3, cat\#516181-C3 and Oa-POLR2A, cat\# 516171; negative control, 3-plex Negative Control Probe, cat\#320871) for $2 \mathrm{~h}$ at $40^{\circ} \mathrm{C}$. Next, slides were washed twice with $1 \mathrm{x}$ Wash Buffer (Advanced Cell Diagnostics, cat\# 310091; 2 min/rinse at RT) followed by sequential tissue application of $50 \mu \mathrm{l}$ of the following each for $30 \mathrm{~min}$ at $40^{\circ} \mathrm{C}$ with 2 min washes using 1x Wash Buffer between applications: RNAscope Multiplex FL v2 Amp 1 (Advanced Cell Diagnostics, cat\# 323101), RNAscope Multiplex FL v2 Amp 2 (Advanced Cell Diagnostics, cat\# 323102), and RNAscope Multiplex FL v2 Amp 3 (Advanced Cell Diagnostics, cat\# 323103). Following final incubation with Amp 3, slides were rinsed with $1 \mathrm{x}$ Wash Buffer twice ( $2 \mathrm{~min} /$ rinse at RT) followed by application of RNAscope Multiplex FL v2 HRP C1 (15 min at $40^{\circ} \mathrm{C}$; Advanced Cell Diagnostics, cat\#323104). Next, sections were incubated with $150 \mu \mathrm{L}$ per slide of Opal
570 (Fisher Scientific; cat\# NC1601878) in RNAscope TSA buffer (Advanced Cell Diagnostics, cat\# 322809) at a final concentration of $1: 1500$ for $30 \mathrm{~min}$ at $40^{\circ} \mathrm{C}$. Following a rinse with $1 \mathrm{x}$ Wash Buffer twice ( $2 \mathrm{~min} /$ rinse at RT), 50 $\mu \mathrm{L}$ of RNAscope ${ }^{\circledR}$ Multiplex FL v2 HRP Blocker (Advanced Cell Diagnostics, cat\# 323107) was applied to tissue for $15 \mathrm{~min}$ at $40^{\circ} \mathrm{C}$. Slides were then rinsed with $1 \mathrm{x}$ Wash Buffer twice ( $2 \mathrm{~min} /$ rinse at RT) followed by application of RNAscope Multiplex FL v2 HRP-C3 (15 min at $40^{\circ} \mathrm{C}$; Advanced Cell Diagnostics, cat\# 323106). Sections were next incubated with $150 \mu \mathrm{L}$ per slide of Opal 690 (Fisher Scientific; cat\# NC1605064) in RNAscope TSA buffer (Advanced Cell Diagnostics, cat\# 322809) at a final concentration of $1: 1500$ for $30 \mathrm{~min}$ at $40^{\circ} \mathrm{C}$, and followed by rinsing of the slide in $1 \mathrm{x}$ Wash Buffer twice $(2 \mathrm{~min} /$ rinse at RT). Then, $50 \mu \mathrm{L}$ of RNAscope ${ }^{\circledR}$ Multiplex FL v2 HRP Blocker (Advanced Cell Diagnostics, cat\# 323107) was applied to tissue for $15 \mathrm{~min}$ at $40^{\circ} \mathrm{C}$. Finally, slides were coverslipped with ProLong Gold Antifade Mountant (Fisher Scientific, cat\# P36930) and stored at $4^{\circ} \mathrm{C}$ until image acquisition.

\section{Immunohistochemistry for kisspeptin or NKB}

For the detection of each antigen, immunohistochemical procedures were performed on free-floating hemisections from FM and FR wethers. Four sections in the middle ARC were selected in each animal from a series of every fifth hypothalamic section (as described above for RNAscope). Each full coronal section was cut at midline with the left and right side of the brain tissue section used for single-label immunoperoxidase detection of kisspeptin and NKB, respectively. See Table 1 for information on all primary antibodies used herein. On day 1 , sections were washed overnight in $0.1 \mathrm{M} \mathrm{PB}$ at $4^{\circ} \mathrm{C}$ on a rocking shaker to remove excess cryoprotectant. All subsequent steps were conducted at RT (except where specified). On day 2 , sections were washed four times $(5 \mathrm{~min}$ each) in 0.1 M PBS (pH 7.4), then placed into $10 \% \mathrm{H}_{2} \mathrm{O}_{2}$ (diluted in $0.1 \mathrm{M}$ PBS) for $10 \mathrm{~min}$ followed by four washes $(5 \mathrm{~min}$ each) in PBS. Tissue was then incubated for $1 \mathrm{~h}$ in a PBS solution containing 0.4\% Triton-X (Sigma Aldrich) and $20 \%$ normal goat serum (NGS; Jackson ImmunoResearch Laboratories, Inc., West Grove, PA) for kisspeptin or $4 \%$ NGS (Jackson) for NKB. Next, to identify kisspeptin or $\mathrm{NKB}$, hemisections were incubated in either primary antibody rabbit anti-kisspeptin-10 (1:50,000; Gift from I. Franceschini, \#566) or rabbit anti-NKB (1:8000; Phoenix Pharmaceuticals, Inc., Burlingame, CA, cat\# H-046-26), diluted in PBS containing $0.4 \%$ Triton X-100 and 4\% 
Table 1 Primary antibody information for immunohistochemistry.

\begin{tabular}{|c|c|c|}
\hline Protein & Antigen sequence & Species raised \\
\hline Kisspeptin-10 & $\begin{array}{l}\text { YNWNSFGLRY-NH2 } \\
\text { Residues } 43-52 \text { of } \\
\text { mouse metastin }\end{array}$ & Rabbit; polyclonal \\
\hline Neurokinin B & DMHDFFVGLM-NH2 & Rabbit; polyclonal \\
\hline
\end{tabular}

\begin{tabular}{l}
\hline Manufacturer. Catalog \# \\
\hline Gift from I. \\
Franceschini, \#566 \\
Phoenix, H-046-26
\end{tabular}

\begin{tabular}{l}
\hline References \\
\hline Franceschini et al. (2006), \\
Goodman et al. (2007), Smith \\
et al. (2011), De Bond et al. (2013) \\
Weems et al. (2016)
\end{tabular}

NGS for $17 \mathrm{~h}$. On day 3, biotinylated goat anti-rabbit IgG inter-pulse interval, and LH pulse amplitude. Individual (1:500; Jackson) and Vectastain ABC-elite (1:500; Vector Laboratories, Burlingame, CA) were applied sequentially for $1 \mathrm{~h}$ each with four washes (5 min each) of PBS between incubations. Hemisections were then placed in a 3,3'-diaminobenzidine tetrahydrochloride (DAB; Fisher Scientific, cat\# AC328005000) solution (10 mg DAB in 50 $\mathrm{mL}$ of $\mathrm{PB}$ with $20 \mu \mathrm{L}$ of $30 \% \mathrm{H}_{2} \mathrm{O}_{2}$ added just prior to use) for $10 \mathrm{~min}$. After four washes (5 min each) in PB, sections were mounted on Superfrost/Plus microscope slides (Fisher Scientific), air dried, dehydrated using a series of increasing alcohol baths, and coverslipped using DPX Mounting Medium (Sigma Aldrich, cat\# 06522).

\section{Primary antibody validation for immunohistochemistry}

The antibody used to detect kisspeptin in this study has been previously validated for use in sheep neural tissue (Franceschini et al. 2006). To validate the specificity of the rabbit anti-NKB antibody (Phoenix) in sheep neural tissue, we conducted a pre-absorption experiment in which the rabbit anti-NKB (1:8000; Phoenix) was incubated with increasing concentrations of the NKB peptide $(0,10,30$ and $75 \mu \mathrm{g} / \mathrm{mL}$; Phoenix, cat \# 046-26) overnight at RT. These working solutions were incubated with two ARC hemisections per animal from four wethers ( $n=2 /$ group) using the single- label immunoperoxidase detection protocol for NKB described above. Pre-absorption of the rabbit anti-NKB with peptide concentrations 10, 30, and $75 \mu \mathrm{g} / \mathrm{mL}$ abolished all NKB-immunoreactivity in the ovine ARC, while the positive control (anti-NKB $+0 \mu \mathrm{g} /$ $\mathrm{mL}$ peptide) showed NKB immunopositive cells and fibers (data not shown).

\section{Data analysis}

\section{LH assay}

LH concentrations were measured in duplicate with an RIA using 50-100 $\mu \mathrm{L}$ of plasma and reagents purchased from the National Hormone and Peptide Program (Torrance, CA) as previously described (Whisnant \& Goodman 1988). Analysis of LH data included mean LH concentration, LH

pulses of LH were identified using previously described criteria (Goodman \& Karsch 1980). Briefly, there were three main criteria: (1) the peak must exceed the sensitivity of the assay, (2) a peak must occur within two data points of the previous nadir, and (3) the peak must exceed a 95\% CI of the previous and following nadirs. LH assay sensitivity was $0.20 \mathrm{ng} / \mathrm{mL}$ with intra- and inter-assay coefficients of variation being 5.69 and $13.89 \%$, respectively.

\section{RNAscope in situ hybridization}

Hemisections processed for simultaneous detection of mRNA for kisspeptin and NKB were analyzed within 3 weeks following the RNAscope procedure, using a Zeiss 880 confocal microscope. The number of cells expressing kisspeptin or NKB mRNA were quantified in the middle ARC by a blinded observer, using images taken with a Plan Apochromat 10x/0.45 objective, with consistent acquisition settings for all hemisections. Images of each hemisection were uploaded to Adobe Photoshop (Adobe, Inc., San Jose, CA), where individual cells were marked in a superimposed image layer. Then, Image $\mathrm{J}$ was used to quantify the number of marked cells within the region of interest. Given the diffuse labeling of both kisspeptin and $\mathrm{NKB}$, a product of abundant mRNA expression (Jolly et al. 2019) (personal communication with Advanced Cell Diagnostics Technical Support), individual cells that expressed mRNA for kisspeptin and NKB (24-30 cells/ animal) were readily identified and randomly selected for integrated density analysis. Confocal z-stack images that encompassed each cell were captured at $1 \mu \mathrm{m}$ optical sections with a Plan Apochromat $63 x / 1.4$ oil objective and acquisition settings were identical for all images including positive and negative control probes. Following the acquisition, an experimenter blinded to the treatment group opened optical slice images in Image J (NIH), converted images to 16-bit, and applied a region of interest (312 pixels x 312 pixels) directly over each cell to determine integrated density. An auto-threshold was recorded for each channel corresponding to the specific label in all optical slices. An average of these thresholds was determined for each of the channels and

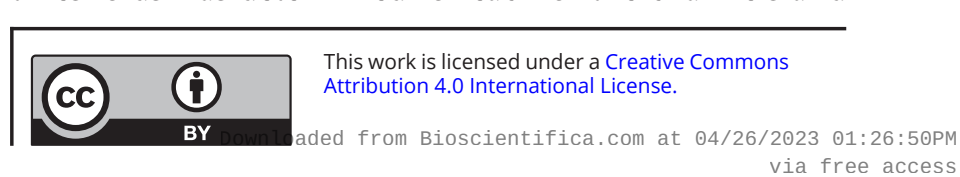



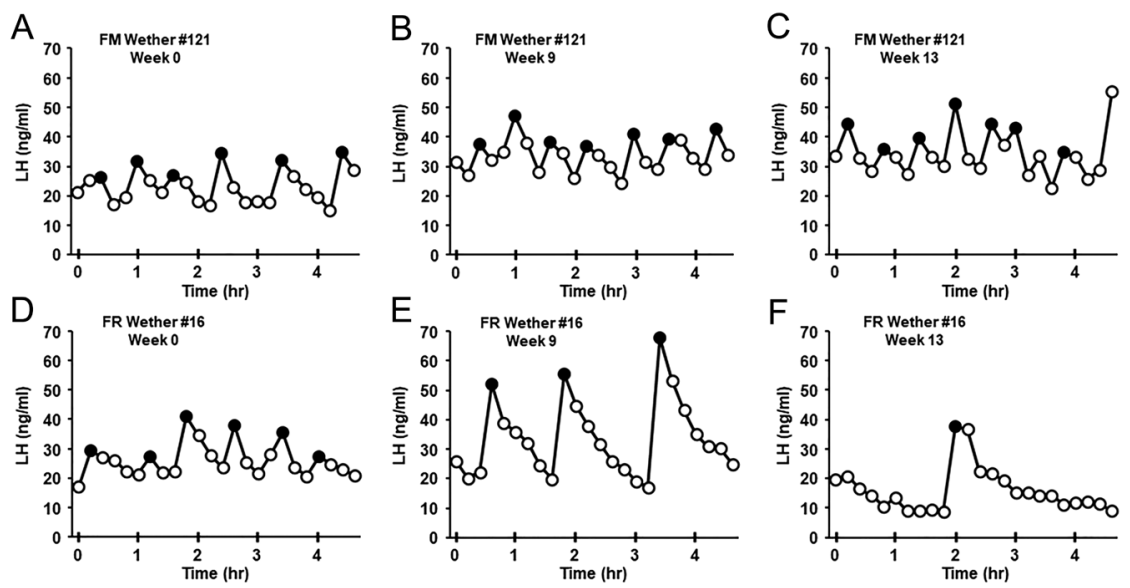

Figure 2 Representative LH profiles (mean \pm S.E.M.)
from a fed to maintain (FM) wether ( $A, B$ and $C$ )
and a feed-restricted (FR) wether (D, E and F) on
Week $0(A, D)$, Week 9 ( $B, E)$, and Week $13(C, F)$.
LH pulses are denoted by closed circles.

used as the fixed threshold intensity for the integrated density analysis. Three optical slices from the center of each cell as determined by the extent of detectable signal throughout the cell were used for analysis, with the sum of the integrated density values calculated per cell and then averaged per animal for statistical comparison.

\section{Immunohistochemistry}

Single-labeled kisspeptin and NKB cells were quantified in the middle ARC by two independent, blinded observers, using brightfield images captured using a Laxco SeBa 2 Digital Microscope System (Fisher Scientific, cat\# NC1347978) with a Plan Apochromat 10x/0.25 objective and a Plan Apochromat 20x/0.40 objective with consistent camera settings across all hemisections. Kisspeptinimmunoreactive (ir) and NKB-ir cell bodies were assessed by an experimenter blinded to treatment groups and identified by brown cytoplasmic staining, and those with defined borders were included in the analysis (Merkley et al. 2012, Nestor et al. 2012). For all animals, images of each hemisection were uploaded to Adobe Photoshop (Adobe, Inc., San Jose, CA), where individual cells were marked in a superimposed image layer. Then, Image J was used to quantify the number of marked cells within the region of interest.

\section{Statistical analysis}

Average body weights, mean LH concentrations, LH interpulse interval, and LH pulse amplitude were analyzed using a repeated measures two-way ANOVA. Data for RNAscope in situ hybridization and immunohistochemistry were analyzed using an unpaired, Student's t-test. Differences were considered to be statistically significant at $P<0.05$.
All analyses were performed using Sigma Plot 11.0 (San Jose, CA).

\section{Results}

\section{Body weights}

Average weekly body weights from FM wethers and FR wethers throughout the study are illustrated in Fig. 1B. There was a treatment $\mathrm{x}$ time interaction $(P<0.001)$ for body weight between groups. At the beginning of the experiment (Week 0), average body weights were not significantly different between FM and FR groups; however, starting at Week 9 through the end of the study (Week 13), average body weights were significantly lower $(P<0.05)$ in FR wethers compared to FM wethers. As designed, the average percent change in pre-study body weight for the FM and FR wethers at Week 13 was $6.79+3.4$ and $-19.82 \pm 1.6 \%$, respectively.

\section{LH data}

Representative LH pulse profiles from FM and FR wethers are shown in Fig. 2. Quantification of mean LH concentration, LH inter-pulse interval, and LH pulse amplitude for FM and FR wethers at Weeks 0,9 , and 13 are illustrated in Fig. 3. There was a significant interaction $(P<0.001)$ of time $\mathrm{x}$ treatment for mean $\mathrm{LH}$ concentration and $\mathrm{LH}$ inter-pulse interval. While not significantly different at Weeks 0 and 9, mean LH concentration at Week 13 was significantly lower $(P<0.05)$ in FR wethers compared to FM wethers (Fig. 3A). In addition, LH inter-pulse interval was significantly greater in FR wethers compared to FM wethers at Week $13(P<0.05$; Fig. 3B), but at Weeks 0 and 9 did not show a significant difference between groups.

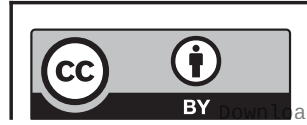



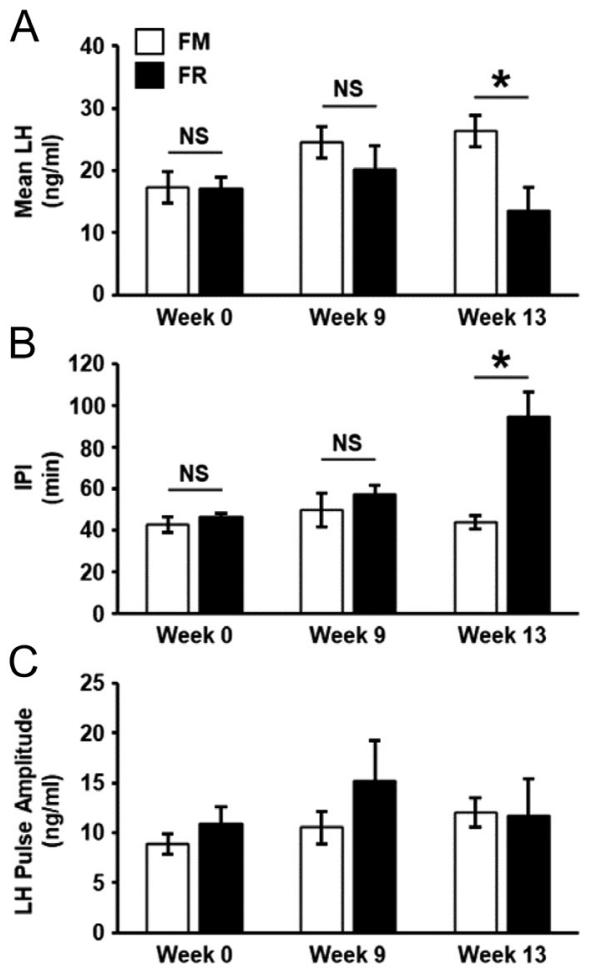

Figure 3 Mean ( \pm S.E.M.) concentrations of LH (A), inter-pulse interval (IPI; B) and $\mathrm{LH}$ pulse amplitude (C) from fed to maintain (FM; $n=6)$ and feed-restricted (FR; $n=8$ ) wethers. (A) Mean LH was significantly lower in FR animals compared to FM wethers at Week $13\left({ }^{*} P<0.05\right)$, while a significant difference was not detected at Week 0 or 9. (B) IPI was significantly greater in FR wethers compared to FM wethers at Week 13 $\left({ }^{*} P<0.05\right)$, but not significantly different at Weeks 0 or 9 . (C) There was no significant effect of feed restriction on LH pulse amplitude $(P>0.05)$.

No significant differences between groups were detected for LH pulse amplitude (Fig. 3C).

\section{Kisspeptin data}

We assessed changes in kisspeptin mRNA and protein in the ARC between FM and FR wethers using RNAscope and immunohistochemistry, respectively. Cells expressing mRNA for kisspeptin were readily visible in the ARC of both FM wethers (Fig. 4A) and FR wethers (Fig. 4B). The average number of kisspeptin cells (Fig. 4C) and the expression of mRNA transcript for kisspeptin per cell (Fig. 4D) were significantly lower $(P<0.05)$ in FR wethers compared to FM wethers.

Cell bodies and fibers expressing protein for kisspeptin were readily visible in the ARC of both FM (Fig. 5A) and FR wethers (Fig. 5B). Analysis of kisspeptin-immunopositive perikarya revealed that FR wethers had significantly fewer numbers of kisspeptin cell bodies $(P<0.01)$ compared to FM wethers (Fig. 5C).

\section{NKB data}

In the same cells that expressed mRNA for kisspeptin, we assessed changes in NKB mRNA and protein in the ARC between FM and FR wethers. Cells expressing mRNA for NKB were readily detectable in the ARC of both FM wethers (Fig. 6A) and FR wethers (Fig. 6B). The average number of NKB cells was significantly lower $(P<0.05)$ in FR wethers compared to FM wethers (Fig. 6C), but the expression of mRNA transcript per cell did not differ between groups $(P>0.05$; Fig. 6D). The percentage of NKB cells that expressed mRNA for kisspeptin in FM and FR wethers was $60.5 \pm 6$ and $64.2 \pm 5 \%$, respectively, while the percentage of kisspeptin cells that expressed mRNA for NKB in FM and FR wethers was $52.0 \pm 7$ and $65.7 \pm 5 \%$, respectively.

Within the ARC of both FM (Fig. 7A) and FR wethers (Fig. 7B), cell bodies and fibers expressing protein for NKB were readily visible. Analysis of the number of NKB-ir cells revealed that FR wethers had significantly fewer $(P<0.01)$ NKB cell bodies compared to FM wethers (Fig. 7C).

\section{Discussion}

The data herein provide evidence of a role for kisspeptin and NKB in the central regulation of LH secretion during undernutrition in male sheep. Chronic feed-restriction in wethers, which produced a significant reduction in LH secretion, resulted in fewer ARC neurons expressing mRNA and protein for kisspeptin and reduced mRNA abundance of kisspeptin in the remaining kisspeptin neurons. In addition, this model of undernutrition resulted in fewer ARC neurons expressing mRNA and protein for NKB. Although there was not a significant effect of feed-restriction on mRNA abundance of NKB in the remaining NKB neurons, the overall nutritionallyinduced inhibition of kisspeptin and NKB provides important neuroanatomical evidence for the central regulation of these neurons during undernutrition.

Sufficient energy intake is an important component of proper reproductive function and as such, it is generally accepted that undernutrition has the capacity to impair reproduction. Earlier work in sheep has demonstrated that undernutrition reduces GnRH release from the hypothalamus (Ebling et al. 1990, Prasad et al. 1993, I'Anson et al. 2000) lending support to the idea that a negative energy balance is sensed at the level of the brain resulting in lower GnRH, and subsequently LH, secretion. Based on previous models in young, gonadectomized 

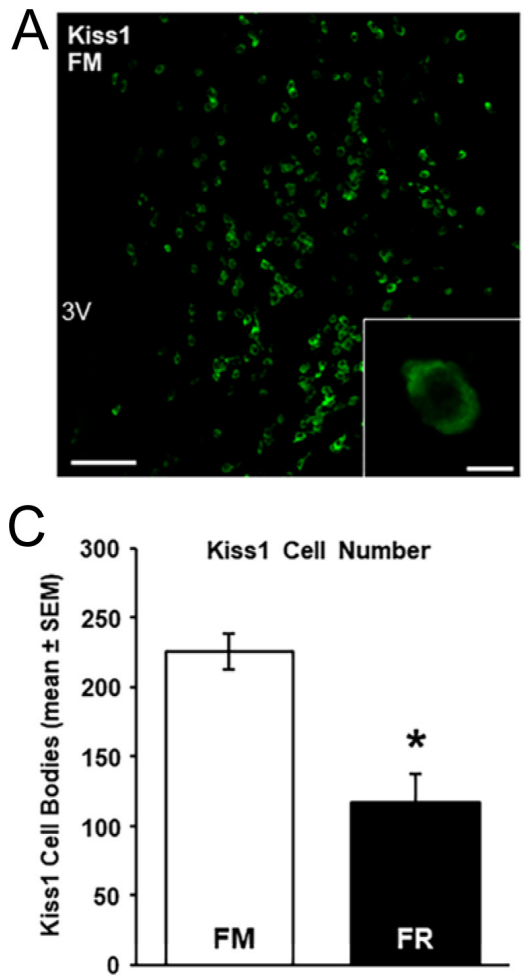
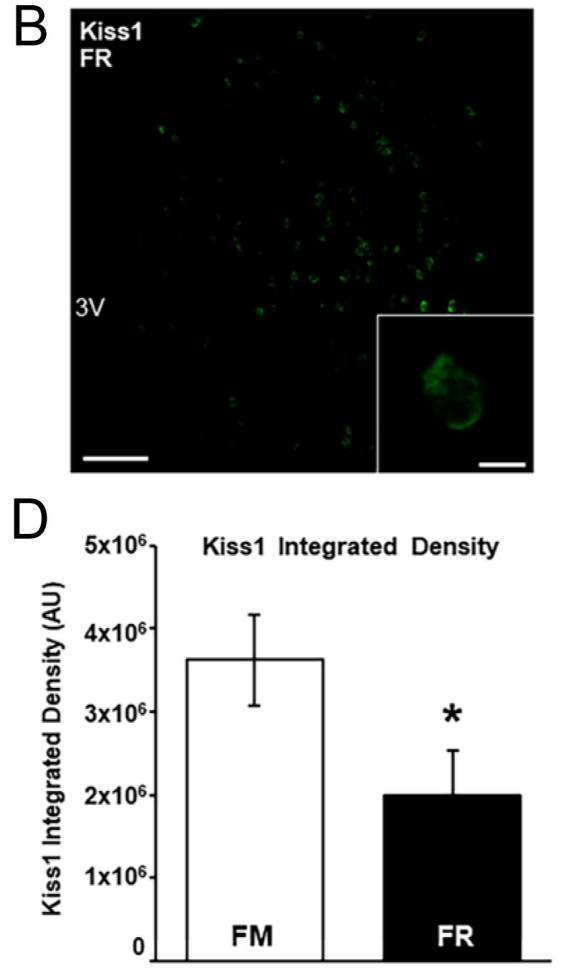

Figure 4 Kiss1 mRNA in the arcuate nucleus (ARC) of fed to maintain (FM) and feed-restricted (FR) wethers. Confocal images (using a 10x objective) of Kiss1 cells from an FM (A) and FR (B) wether. Insets show high magnification confocal images (1 $\mu \mathrm{m}$ optical section, $63 \mathrm{x}$ objective) of representative Kiss1 cells in a FM (A inset) and a FR (B inset) wether. (C) Mean ( \pm S.E.M.) number of Kiss1 cell bodies in the ARC were significantly lower ( ${ }^{*} P<0.05$ ) in FR wethers compared to FM wethers. (D) Mean ( \pm S.E.M.) integrated density of Kiss1 mRNA per ARC cell was significantly lower $\left({ }^{*} P<0.05\right)$ in FR wethers $(n=8)$ compared to FM wethers $(n=6)$. Scale bars, $100 \mu \mathrm{m}$. Scale bars for insets, $10 \mu \mathrm{m}$. For print clarity, Kiss1 mRNA has been pseudocolored green in these images. $3 \mathrm{~V}$, third cerebroventricle. sheep (Foster \& Olster 1985, Adam et al. 1997, McManus et al. 2005), we established a model of undernutrition in wethers that produces a robust reduction of $\mathrm{LH}$ secretion. Given that our study used LH secretion as an index of GnRH release, it is possible that undernutrition decreased pituitary responsiveness to GnRH. However, since others have shown that exogenous GnRH administration elicits LH secretion in growth-restricted sheep (Ebling et al. 1990) and rodents (Bronson 1988), it is more likely that the primary mechanism whereby undernutrition decreases LH secretion is through a central-mediated pathway regulating $\mathrm{GnRH}$ release, given data herein that feed restriction reduced $\mathrm{LH}$ pulse frequency, but not $\mathrm{LH}$ pulse amplitude. Moreover, as the final common conduit from the CNS controlling reproduction, GnRH neurons play an integral part of the central mechanism whereby undernutrition limits reproduction, but GnRH neurons do not appear to be direct targets of leptin or insulin (Finn et al. 1998, Quennell et al. 2009, Louis et al. 2011, Cernea et al. 2016). Therefore, afferent neurons likely mediate the loss of these satiety signals during times of undernutrition.

As a potent stimulator of $\mathrm{GnRH}$ neurons, kisspeptin plays an essential role in pulsatile GnRH/LH secretion and is one of the most likely neuropeptide candidates to be impacted by undernutrition. Indeed, others have shown that chronic undernutrition reduces ARC mRNA for kisspeptin in rodents and sheep (Backholer et al. 2010a, True et al. 2011, Yang et al. 2016). While it is common to make inferences on changes in protein from mRNA, our study examined mRNA and protein for ARC kisspeptin, revealing that both are reduced with chronic undernutrition in male sheep. Shorter bouts of nutritional challenges have produced inconsistent results in kisspeptin expression. For example, withholding feed
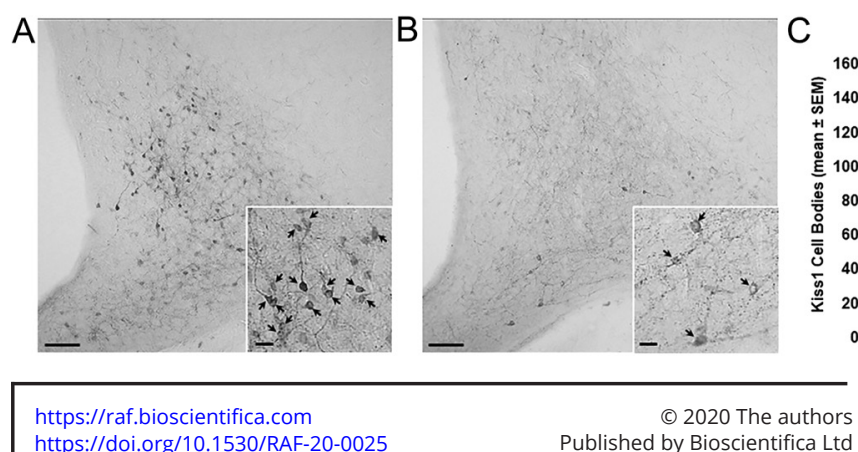

https://raf.bioscientifica.com https://doi.org/10.1530/RAF-20-0025 (c) 2020 The authors Published by Bioscientifica Ltd
Figure 5 ( $A$ and $B$ ) Representative photomicrographs (using a 10x objective) showing kisspeptin-immunoreactive (ir) cells and fibers in the middle arcuate nucleus (ARC) from a fed to maintain (FM; A) wether and a feed-restricted (FR; B) wether. Insets (using a 20x objective), arrows indicate kisspeptin-ir cell bodies. (C) Mean (士S.E.M.) number of kisspeptin-ir cell bodies per hemisection in the ARC was significantly lower ( ${ }^{*} P$ $<0.05)$ in FR wethers $(n=8)$ compared to FM wethers $(n=6)$. Scale bars, $200 \mu \mathrm{m}$. Scale bars for insets, $25 \mu \mathrm{m}$.
Kisspeptin Cell Number

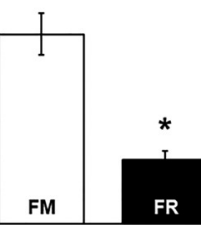

This work is licensed under a Creative Commons Attribution 4.0 International License. 


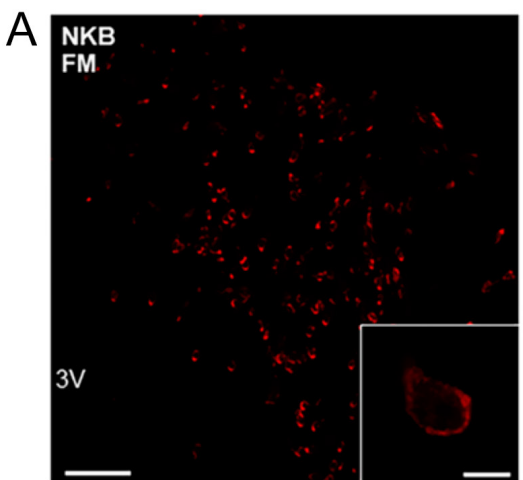

C

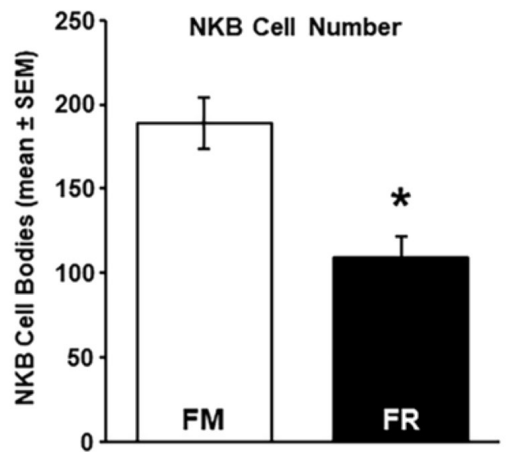

B NKB

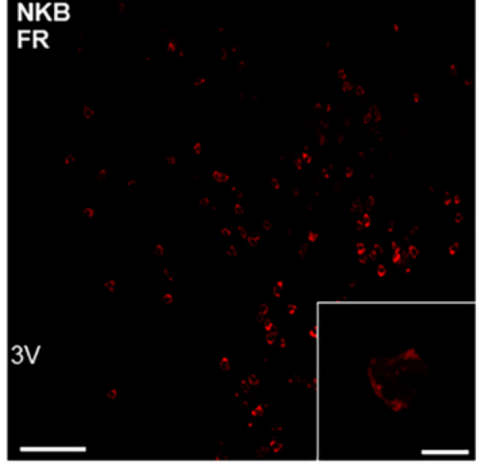

D

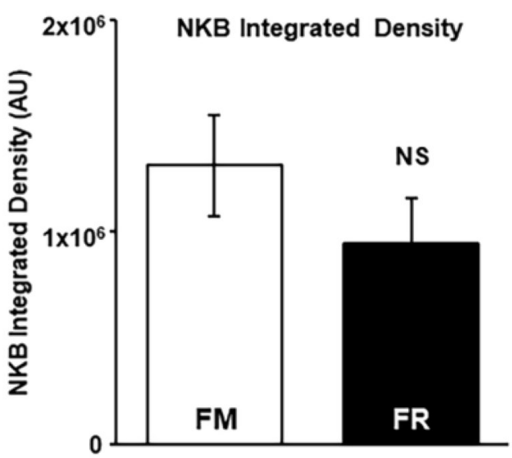

Figure 6 NKB mRNA in the arcuate nucleus (ARC) of fed to maintain (FM) and feed-restricted (FR) wethers. Confocal images (using a 10x objective)) of NKB cells from an FM (A) and FR wether (B). Insets show high magnification confocal images (1 $\mu \mathrm{m}$ optical section, $63 \mathrm{x}$ objective) of

representative NKB cells in a FM (A inset) and a FR (B inset) wether. (C) Mean ( \pm S.E.M.) number of NKB cell bodies in the ARC were significantly fewer ( ${ }^{*} P$ $<0.05)$ in FR wethers $(n=8)$ compared to FM wethers $(n=6)$. (D) Mean integrated density of NKB mRNA per ARC cell was not significantly (NS) different between groups. Scale bars, $100 \mu \mathrm{m}$. Scale bars for insets, $10 \mu \mathrm{m}$. 3V, third cerebroventricle. for 3 days in sheep reduced mRNA (Wang et al. 2012) and protein (Polkowska et al. 2015) for ARC kisspeptin, but feed restriction for 10 days in gilts, which resulted in a significant difference in body weight compared to controls, increased mean $\mathrm{LH}$ and $\mathrm{LH}$ pulse amplitude while having no effect on mRNA of ARC kisspeptin (Thorson et al. 2018). While species differences may exist, another possible explanation for this discrepancy is that the severity of feed restriction (withholding feed vs feed restriction) likely impacts the central expression of kisspeptin. Furthermore, while our model of feed restriction was similar to that of Thorson et al. (2018), the length of feed restriction is also likely a contributing factor as several weeks were needed to produce a reduction in $\mathrm{LH}$ secretion in our wethers.
Coexpressed within the vast majority of kisspeptin neurons in the ARC (Moore et al. 2018), NKB has also been shown to play an active stimulatory role in GnRH/LH pulsatility through direct stimulation of ARC kisspeptin neurons (Goodman et al. 2013). While it has been reported that undernutrition reduces mRNA for NKB in rodents (True et al. 2011, Yang et al. 2016), our study is the first evidence in sheep that undernutrition reduces ARC NKB expression. There is evidence in gilts that feed restriction increases mRNA for ARC NKB (Thorson et al. 2018), and while this is not in agreement with the effect of feed restriction on NKB in other species, greater expression of NKB coincided with increased LH concentrations, and further work is needed to determine if NKB plays a role in modulating GnRH/LH pulse amplitude. Furthermore,
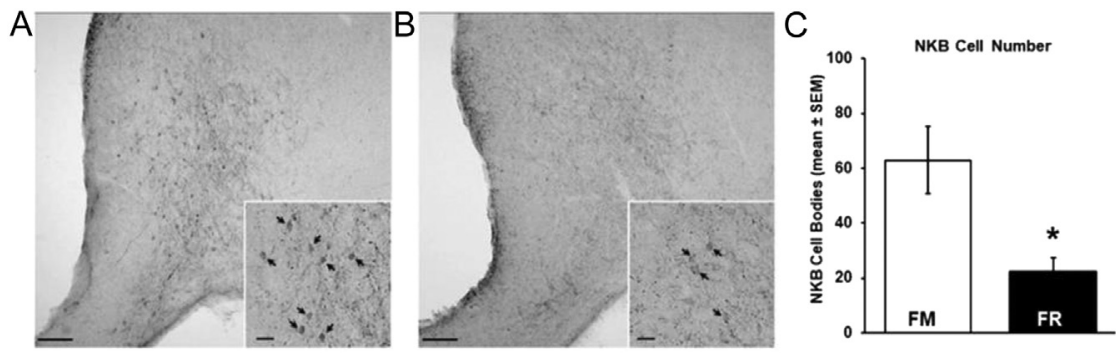

Figure 7 ( $A$ and $B$ ) Representative photomicrographs (using a 10x objective) showing NKB-immunoreactive (ir) cells and fibers in the middle arcuate nucleus (ARC) from a fed to maintain (FM; A) wether and a feed-restricted (FR; B) wether. Insets (using a 20x objective), arrows indicate NKB-ir cell bodies. (C) Mean (士s.E.M.) number of NKB-ir cells per hemisection in the middle ARC was significantly lower $(* P<0.05)$ in FR wethers $(n=8)$ compared to FM wethers $(n=6)$. Scale bars, $200 \mu \mathrm{m}$. Scale bars for insets, $25 \mu \mathrm{m}$. https://raf.bioscientifica.com https://doi.org/10.1530/RAF-20-0025 (c) 2020 The authors Published by Bioscientifica Ltd

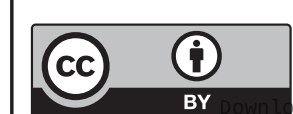

This work is licensed under a Creative Commons Attribution 4.0 International License. 
kisspeptin cell numbers (detected via mRNA and protein) and kisspeptin mRNA abundance per cell were both reduced in our study, but only NKB cell numbers were reduced with no change in NKB mRNA abundance. While there is evidence from non-nutritional models to support differential regulation of peptides within neurons that coexpress kisspeptin and NKB (Cheng et al. 2010, Nestor et al. 2012, Overgaard et al. 2014), one limitation of the current study is that mRNA abundance for NKB was only assessed within cells that expressed both kisspeptin and NKB. Thus, we may have missed any changes that would have occurred in NKB expression within non-kisspeptin neurons, which appear to be more abundant in males than females based on work from others (Goodman et al. 2007, Ramaswamy et al. 2010, Hrabovszky et al. 2012) and our data herein. Albeit, the decrease in total NKBexpressing cells is likely sufficient to result in the loss of stimulatory drive to ARC kisspeptin neurons, and thus reduced $\mathrm{GnRH} / \mathrm{LH}$ pulsatility.

Dynorphin, also highly coexpressed in ARC neurons with kisspeptin and NKB (Moore et al. 2018), differs from these stimulatory neuropeptides in that it has an inhibitory role in regulating GnRH/LH secretion. Dynorphin has been shown to mediate progesteronenegative feedback on LH secretion in adult rats (Gallo et al. 1990) and ewes (Foradori et al. 2005) and the current working model for dynorphin supports a role in the termination of individual GnRH/LH pulses (Navarro et al. 2009, Grachev et al. 2012a, Weems et al. 2018). As for a role linking energy balance to reproduction, food deprivation has inconsistent results with some reporting an increase in dynorphin expression (Berman et al. 1997, Herve \& Fellmann 1997, Shoham et al. 2000), while a more recent report has shown that food deprivation has no effect on ARC dynorphin expression and that chronic food restriction reduces ARC dynorphin expression in ovariectomized female mice (Yang et al. 2016). While not a primary focus of this study, we did attempt to measure dynorphin immunoreactivity between FM and FR wethers, but were unable to detect the expression of ARC dynorphin in either group (data not shown). This appears to be a limitation of immunohistochemistry in young animals as we and others (Lopez et al. 2016) can detect dynorphin in adult, luteal phase ewes, but not in young male or female sheep. However, given the presence of dynorphin receptors on both GnRH neurons and KNDy neurons (Lopez et al. 2016, Weems et al. 2016), the nutritional influence of dynorphin on LH secretion could be exerted directly, indirectly, or both, and should receive further investigation.
Although a clear inhibition of undernutrition on kisspeptin and NKB exists in wethers, it is still unclear if this effect of nutrition is a direct regulation or that of afferent input to these essential neurons. Work in sheep using single-cell laser capture has reported that essentially all ARC kisspeptin neurons express leptin receptors (Backholer et al. 2010b), while another study using immunohistochemistry for pSTAT3, a marker of direct leptin receptor activation, has shown that leptin administration in adult ewes failed to show evidence of functional leptin receptors in ARC kisspeptin neurons (Louis et al. 2011). Alternatively, work in sheep has shown that the vast majority of kisspeptin neurons, but not POA kisspeptin or GnRH neurons, express insulin receptors (Cernea et al. 2016), thus supporting the idea that insulin may have a direct action on these neurons; however, it remains to be shown whether ARC kisspeptin neurons are activated in response to exogenous insulin during feed restriction. Moreover, while this study examined a central mechanism independent of gonadal sex steroids, further investigation is needed to determine how undernutrition acts within the hypothalamus to increase sensitivity to sex steroid negative feedback on GnRH/LH secretion (Foster \& Olster 1985, Beckett et al. 1997).

In conclusion, the data here support the hypothesis that chronic feed restriction reduces kisspeptin and NKB expression in the ARC of young, castrated male sheep and that both of these reproductively critical neuropeptides play a role in mediating the effect of undernutrition on GnRH/LH secretion. By using RNAscope and immunohistochemistry, we were able to assess changes in mRNA and protein, respectively, for kisspeptin and NKB within the same study. Furthermore, this is the first evidence in sheep for the nutritional regulation of NKB expression. Taken together, these data clearly demonstrate that even in the absence of gonadal sex steroids, the inhibition of two key stimulatory neuropeptides, kisspeptin and NKB during chronic undernutrition plays an important role in the central suppression of GnRH/LH release.

\section{Declaration of interest}

The authors declare that there is no conflict of interest that could be perceived as prejudicing the impartiality of the research reported.

\section{Funding}

This work was supported by USDA National Institute of Food and Agriculture Hatch Project 1012905 and by National Institute of Food and Agriculture Grant no. 2019-67016-29408.

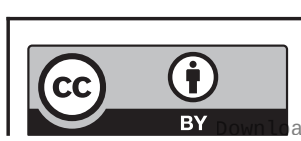

This work is licensed under a Creative Commons Attribution 4.0 International License. 


\section{Author contribution statement}

C C N involved in project design and management. A N R, S L S, K S, J R S and C C N contributed to the collection of blood samples, body weight data, and brain tissue. C M M and A N R involved in implementation of IHC. S LS and $\mathrm{K} \mathrm{H}$ contributed to the development of ovine RNAscope. S L S involved in implementation of RNAscope. C M M and C C N involved in data analysis and writing of this manuscript.

\section{Acknowledgements}

We thank Tabatha Wilson (North Carolina State University Metabolic Education Unit) for care of animals, Dr Al Parlow and the National Hormone and Peptide Program for reagents used to measure $\mathrm{LH}$, and $\mathrm{Dr}$ Isabelle Franceschini for the kind gift of kisspeptin antisera. In addition, we thank Maggie Cummings, Alyx Fisk, Haley Johnson, Ashlyn Matthews, Marlyn Thompson, and Alyssa Valentine for their assistance with conducting this research (animal care, blood collection, tissue collection, preparing laboratory solutions). We also acknowledge the use of the Cellular and Molecular Imaging Facility (CMIF) at North Carolina State University, which is supported by the State of North Carolina and the National Science Foundation

\section{References}

Adam CL, Findlay PA, Kyle CE, Young P \& Mercer JG 1997 Effect of chronic food restriction on pulsatile luteinizing hormone secretion and hypothalamic neuropeptide $\mathrm{Y}$ gene expression in castrate male sheep. Journal of Endocrinology 152 329-337. (https://doi. org/10.1677/joe.0.1520329)

Ahn T, Fergani C, Coolen LM, Padmanabhan V \& Lehman MN 2015 Prenatal testosterone excess decreases neurokinin 3 receptor immunoreactivity within the arcuate nucleus KNDy cell population. Journal of Neuroendocrinology 27 100-110. (https://doi.org/10.1111/ jne.12244)

Amstalden M, Coolen LM, Hemmerle AM, Billings HJ, Connors JM, Goodman RL \& Lehman MN 2010 Neurokinin 3 receptor immunoreactivity in the septal region, preoptic area and hypothalamus of the female sheep: colocalisation in neurokinin $\mathrm{B}$ cells of the arcuate nucleus but not in gonadotrophin-releasing hormone neurones. Journal of Neuroendocrinology 22 1-12. (https:// doi.org/10.1111/j.1365-2826.2009.01930.x)

Backholer K, Bowden M, Gamber K, Bjorbaek C, Iqbal J \& Clarke IJ $2010 a$ Melanocortins mimic the effects of leptin to restore reproductive function in lean hypogonadotropic ewes. Neuroendocrinology 91 27-40. (https://doi.org/10.1159/000260060)

Backholer K, Smith JT, Rao A, Pereira A, Iqbal J, Ogawa S, Li Q \& Clarke IJ $2010 b$ Kisspeptin cells in the ewe brain respond to leptin and communicate with neuropeptide $\mathrm{Y}$ and proopiomelanocortin cells. Endocrinology 151 2233-2243. (https://doi.org/10.1210/en.20091190)

Beckett JL, Sakurai H, Famula TR \& Adams TE 1997 Negative feedback potency of estradiol is increased in orchidectomized sheep during chronic nutrient restriction. Biology of Reproduction 57 408-414. (https://doi.org/10.1095/biolreprod57.2.408)

Berman Y, Devi L, Spangler R, Kreek MJ \& Carr KD 1997 Chronic food restriction and streptozotocin-induced diabetes differentially alter prodynorphin mRNA levels in rat brain regions. Brain Research: Molecular Brain Research 46 25-30. (https://doi.org/10.1016/s0169$328 x(96) 00175-1)$

Billings HJ, Connors JM, Altman SN, Hileman SM, Holaskova I, Lehman MN, Mcmanus CJ, Nestor CC, Jacobs BH \& Goodman RL
2010 Neurokinin B acts via the neurokinin-3 receptor in the retrochiasmatic area to stimulate luteinizing hormone secretion in sheep. Endocrinology 151 3836-3846. (https://doi.org/10.1210/ en.2010-0174)

Bosch MA, Tonsfeldt KJ \& Ronnekleiv OK 2013 mRNA expression of ion channels in GnRH neurons: subtype-specific regulation by 17betaestradiol. Molecular and Cellular Endocrinology 367 85-97. (https://doi. org/10.1016/j.mce.2012.12.021)

Bronson FH 1988 Effect of food manipulation on the GnRH-LH-estradiol axis of young female rats. American Journal of Physiology $\mathbf{2 5 4}$ R616-R621. (https://doi.org/10.1152/ajpregu.1988.254.4.R616)

Castellano JM, Navarro VM, Fernandez-Fernandez R, Nogueiras R, Tovar S, Roa J, Vazquez MJ, Vigo E, Casanueva FF, Aguilar E, et al. 2005 Changes in hypothalamic KiSS-1 system and restoration of pubertal activation of the reproductive axis by kisspeptin in undernutrition. Endocrinology 146 3917-3925. (https://doi. org/10.1210/en.2005-0337)

Cernea M, Phillips R, Padmanabhan V, Coolen LM \& Lehman MN 2016 Prenatal testosterone exposure decreases colocalization of insulin receptors in kisspeptin/neurokinin B/dynorphin and agouti-related peptide neurons of the adult ewe. European Journal of Neuroscience $\mathbf{4 4}$ 2557-2568. (https://doi.org/10.1111/ejn.13373)

Chakravarty I, Sreedhar R, Ghosh KK, Card D \& Bulusu S 1982 Circulating gonadotropin profile in severe cases of protein calorie malnutrition. Fertility and Sterility 37 650-654. (https://doi. org/10.1016/s0015-0282(16)46277-1)

Cheng G, Coolen LM, Padmanabhan V, Goodman RL \& Lehman MN 2010 The kisspeptin/neurokinin B/dynorphin (KNDy) cell population of the arcuate nucleus: sex differences and effects of prenatal testosterone in sheep. Endocrinology 151 301-311. (https:// doi.org/10.1210/en.2009-0541)

Cravo RM, Margatho LO, Osborne-Lawrence S, Donato Jr J, Atkin S, Bookout AL, Rovinsky S, Frazao R, Lee CE, Gautron L, et al. 2011 Characterization of Kiss1 neurons using transgenic mouse models. Neuroscience 173 37-56. (https://doi.org/10.1016/j. neuroscience.2010.11.022)

Day ML, Imakawa K, Zalesky DD, Kittok RJ \& Kinder JE 1986 Effects of restriction of dietary energy intake during the prepubertal period on secretion of luteinizing hormone and responsiveness of the pituitary to luteinizing hormone-releasing hormone in heifers. Journal of Animal Science 62 1641-1648. (https://doi.org/10.2527/ jas1986.6261641x)

De Bond JA, Li Q, Millar RP, Clarke IJ \& Smith JT 2013 Kisspeptin signaling is required for the luteinizing hormone response in anestrous ewes following the introduction of males. PLOS ONE $\mathbf{8}$ e57972. (https://doi.org/10.1371/journal.pone.0057972)

de Roux N, Genin E, Carel JC, Matsuda F, Chaussain JL \& Milgrom E 2003 Hypogonadotropic hypogonadism due to loss of function of the KiSS1-derived peptide receptor GPR54. PNAS 100 10972-10976. (https://doi.org/10.1073/pnas.1834399100)

Ebling FJ, Wood RI, Karsch FJ, Vannerson LA, Suttie JM, Bucholtz DC, Schall RE \& Foster DL 1990 Metabolic interfaces between growth and reproduction. III. Central mechanisms controlling pulsatile luteinizing hormone secretion in the nutritionally growth-limited female lamb. Endocrinology 126 2719-2727. (https://doi.org/10.1210/ endo-126-5-2719)

Finn PD, Cunningham MJ, Pau KY, Spies HG, Clifton DK \& Steiner RA 1998 The stimulatory effect of leptin on the neuroendocrine reproductive axis of the monkey. Endocrinology 139 4652-4662. (https://doi.org/10.1210/endo.139.11.6297)

Fitzgerald J, Michel F \& Butler WR 1982 Growth and sexual maturation in ewes: dietary and seasonal effects modulating luteinizing hormone secretion and first ovulation. Journal of Animal Science 55 1431-1440. (https://doi.org/10.2527/jas1982.5561431x)

Foradori CD, Goodman RL, Adams VL, Valent M \& Lehman MN 2005 Progesterone increases dynorphin A concentrations in cerebrospinal

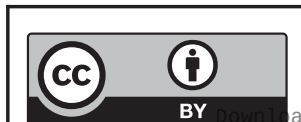

This work is licensed under a Creative Commons Attribution 4.0 International License. 
fluid and preprodynorphin messenger ribonucleic acid levels in a subset of dynorphin neurons in the sheep. Endocrinology 146 1835-1842. (https://doi.org/10.1210/en.2004-1326)

Foradori CD, Amstalden M, Goodman RL \& Lehman MN 2006 Colocalisation of dynorphin A and neurokinin B immunoreactivity in the arcuate nucleus and median eminence of the sheep. Journal of Neuroendocrinology 18 534-541. (https://doi.org/10.1111/j.13652826.2006.01445.x)

Foster DL \& Olster DH 1985 Effect of restricted nutrition on puberty in the lamb: patterns of tonic luteinizing hormone (LH) secretion and competency of the LH surge system. Endocrinology 116 375-381. (https://doi.org/10.1210/endo-116-1-375)

Franceschini I, Lomet D, Cateau M, Delsol G, Tillet Y \& Caraty A 2006 Kisspeptin immunoreactive cells of the ovine preoptic area and arcuate nucleus co-express estrogen receptor alpha. Neuroscience Letters 401 225-230. (https://doi.org/10.1016/j.neulet.2006.03.039)

Gallo RV, Bona-Gallo A \& O'Sullivan D 1990 Ovarian steroid regulation of pulsatile luteinizing hormone release during early gestation in the rat. Journal of Neuroendocrinology 2 883-888. (https://doi org/10.1111/j.1365-2826.1990.tb00655.x)

Garcia-Galiano D, Van Ingen Schenau D, Leon S, Krajnc-Franken MA, Manfredi-Lozano M, Romero-Ruiz A, Navarro VM, Gaytan F, Van Noort PI, Pinilla L, et al. 2012 Kisspeptin signaling is indispensable for neurokinin B, but not glutamate, stimulation of gonadotropin secretion in mice. Endocrinology 153 316-328. (https://doi. org/10.1210/en.2011-1260)

Glass AR \& Swerdloff RS 1980 Nutritional influences on sexual maturation in the rat. Federation Proceedings 39 2360-2364.

Goodman RL \& Karsch FJ 1980 Pulsatile secretion of luteinizing hormone: differential suppression by ovarian steroids. Endocrinology 107 1286-1290. (https://doi.org/10.1210/endo-107-5-1286)

Goodman RL, Lehman MN, Smith JT, Coolen LM, De Oliveira CV, Jafarzadehshirazi MR, Pereira A, Iqbal J, Caraty A, Ciofi P, et al 2007 Kisspeptin neurons in the arcuate nucleus of the ewe express both dynorphin A and neurokinin B. Endocrinology 148 5752-5760. (https://doi.org/10.1210/en.2007-0961)

Goodman RL, Hileman SM, Nestor CC, Porter KL, Connors JM, Hardy SL, Millar RP, Cernea M, Coolen LM \& Lehman MN 2013 Kisspeptin, neurokinin $\mathrm{B}$, and dynorphin act in the arcuate nucleus to control activity of the GnRH pulse generator in ewes. Endocrinology 154 4259-4269. (https://doi.org/10.1210/en.2013-1331)

Grachev P, Li XF, Kinsey-Jones JS, Di Domenico AL, Millar RP, Lightman SL \& O'Byrne KT 2012a Suppression of the GnRH pulse generator by neurokinin B involves a $\mathrm{\kappa}$-opioid receptor-dependent mechanism. Endocrinology 153 4894-4904. (https://doi.org/10.1210/ en.2012-1574)

Grachev P, Li XF, Lin YS, Hu MH, Elsamani L, Paterson SJ, Millar RP, Lightman SL \& O'Byrne KT 2012b GPR54-dependent stimulation of luteinizing hormone secretion by neurokinin B in prepubertal rats. PLOS ONE 7 e44344. (https://doi.org/10.1371/journal.pone.0044344)

Hakansson ML, Brown H, Ghilardi N, Skoda RC \& Meister B 1998 Leptin receptor immunoreactivity in chemically defined target neurons of the hypothalamus. Journal of Neuroscience 18 559-572. (https://doi. org/10.1523/JNEUROSCI.18-01-00559.1998)

Herbison AE, De Tassigny Xd, Doran J \& Colledge WH 2010 Distribution and postnatal development of Gpr54 gene expression in mouse brain and gonadotropin-releasing hormone neurons. Endocrinology 151 312-321. (https://doi.org/10.1210/en.2009-0552)

Herve C \& Fellmann D 1997 Changes in rat melanin-concentrating hormone and dynorphin messenger ribonucleic acids induced by food deprivation. Neuropeptides 31 237-242. (https://doi. org/10.1016/s0143-4179(97)90054-8)

Hrabovszky E, Sipos MT, Molnar CS, Ciofi P, Borsay BÁ, Gergely P, Herczeg L, Bloom SR, Ghatei MA, Dhillo WS, et al. 2012 Low degree of overlap between kisspeptin, neurokinin B, and dynorphin immunoreactivities in the infundibular nucleus of young male human subjects challenges the KNDy neuron concept. Endocrinology 153 4978-4989. (https://doi.org/10.1210/en.2012-1545)

I'Anson H, Manning JM, Herbosa CG, Pelt J, Friedman CR, Wood RI, Bucholtz DC \& Foster DL 2000 Central inhibition of gonadotropin-releasing hormone secretion in the growth-restricted hypogonadotropic female sheep. Endocrinology 141 520-527. (https://doi.org/10.1210/endo.141.2.7308)

Irwig MS, Fraley GS, Smith JT, Acohido BV, Popa SM, Cunningham MJ, Gottsch ML, Clifton DK \& Steiner RA 2004 Kisspeptin activation of gonadotropin releasing hormone neurons and regulation of KiSS-1 mRNA in the male rat. Neuroendocrinology 80 264-272. (https://doi. org $/ 10.1159 / 000083140$ )

Jayasena CN, Nijher GM, Chaudhri OB, Murphy KG, Ranger A, Lim A, Patel D, Mehta A, Todd C, Ramachandran R, et al. 2009 Subcutaneous injection of kisspeptin-54 acutely stimulates gonadotropin secretion in women with hypothalamic amenorrhea, but chronic administration causes tachyphylaxis. Journal of Clinical Endocrinology and Metabolism 94 4315-4323. (https://doi. org/10.1210/jc.2009-0406)

Jolly S, Lang V, Koelzer VH, Sala Frigerio C, Magno L, Salinas PC, Whiting P \& Palomer E 2019 Single-cell quantification of mRNA expression in the human brain. Scientific Reports 9 12353. (https:// doi.org/10.1038/s41598-019-48787-w)

Lents CA, Heidorn NL, Barb CR \& Ford JJ 2008 Central and peripheral administration of kisspeptin activates gonadotropin but not somatotropin secretion in prepubertal gilts. Reproduction 135 879-887. (https://doi.org/10.1530/REP-07-0502)

Lopez JA, Bedenbaugh MN, Mccosh RB, Weems PW, Meadows LJ, Wisman B, Coolen LM, Goodman RL \& Hileman SM 2016 Does dynorphin play a role in the onset of puberty in female sheep? Journal of Neuroendocrinology 28 jne12445. (https://doi.org/10.1111/jne.12445)

Louis GW, Greenwald-Yarnell M, Phillips R, Coolen LM, Lehman MN \& Myers Jr MG 2011 Molecular mapping of the neural pathways linking leptin to the neuroendocrine reproductive axis. Endocrinology 152 2302-2310. (https://doi.org/10.1210/en.2011-0096)

Magee C, Foradori CD, Bruemmer JE, Arreguin-Arevalo JA, Mccue PM, Handa RJ, Squires EL \& Clay CM 2009 Biological and anatomical evidence for kisspeptin regulation of the hypothalamic-pituitarygonadal axis of estrous horse mares. Endocrinology 150 2813-2821. (https://doi.org/10.1210/en.2008-1698)

Mason AO, Greives TJ, Scotti MA, Levine J, Frommeyer S, Ketterson ED, Demas GE \& Kriegsfeld LJ 2007 Suppression of kisspeptin expression and gonadotropic axis sensitivity following exposure to inhibitory day lengths in female Siberian hamsters. Hormones and Behavior 52 492-498. (https://doi.org/10.1016/j.yhbeh.2007.07.004)

McManus CJ, Goodman RL, Llanza NV, Valent M, Dobbins AB, Connors JM \& Hileman SM 2005 Inhibition of luteinizing hormone secretion by localized administration of estrogen, but not dihydrotestosterone, is enhanced in the ventromedial hypothalamus during feed restriction in the young wether. Biology of Reproduction 73 781-789. (https://doi.org/10.1095/biolreprod.105.042275)

Merkley CM, Porter KL, Coolen LM, Hileman SM, Billings HJ, Drews S, Goodman RL \& Lehman MN 2012 KNDy (kisspeptin/neurokinin B/ dynorphin) neurons are activated during both pulsatile and surge secretion of LH in the ewe. Endocrinology 153 5406-5414. (https:// doi.org/10.1210/en.2012-1357)

Moore AM, Coolen LM, Porter DT, Goodman RL \& Lehman MN 2018 KNDy cells revisited. Endocrinology 159 3219-3234. (https://doi. org/10.1210/en.2018-00389)

Navarro VM, Castellano JM, Fernandez-Fernandez R, Barreiro ML, Roa J, Sanchez-Criado JE, Aguilar E, Dieguez C, Pinilla L \& Tena-Sempere M 2004 Developmental and hormonally regulated messenger ribonucleic acid expression of KiSS-1 and its putative receptor, GPR54, in rat hypothalamus and potent luteinizing hormonereleasing activity of KiSS-1 peptide. Endocrinology 145 4565-4574. (https://doi.org/10.1210/en.2004-0413) 
Navarro VM, Gottsch ML, Chavkin C, Okamura H, Clifton DK \& Steiner RA 2009 Regulation of gonadotropin-releasing hormone secretion by kisspeptin/dynorphin/neurokinin B neurons in the arcuate nucleus of the mouse. Journal of Neuroscience $\mathbf{2 9}$ 11859-11866. (https://doi.org/10.1523/JNEUROSCI.1569-09.2009)

Navarro VM, Castellano JM, Mcconkey SM, Pineda R, Ruiz-Pino F, Pinilla L, Clifton DK, Tena-Sempere M \& Steiner RA 2011 Interactions between kisspeptin and neurokinin B in the control of GnRH secretion in the female rat. American Journal of Physiology: Endocrinology and Metabolism 300 E202-E210. (https://doi. org/10.1152/ajpendo.00517.2010)

Navarro VM, Ruiz-Pino F, Sanchez-Garrido MA, Garcia-Galiano D, Hobbs SJ, Manfredi-Lozano M, Leon S, Sangiao-Alvarellos S, Castellano JM, Clifton DK, et al. 2012 Role of neurokinin B in the control of female puberty and its modulation by metabolic status. Journal of Neuroscience 32 2388-2397. (https://doi.org/10.1523/ JNEUROSCI.4288-11.2012)

Nestor CC, Briscoe AM, Davis SM, Valent M, Goodman RL \& Hileman SM 2012 Evidence of a role for kisspeptin and neurokinin B in puberty of female sheep. Endocrinology 153 2756-2765. (https://doi. org/10.1210/en.2011-2009)

Ohkura S, Takase K, Matsuyama S, Mogi K, Ichimaru T, Wakabayashi Y, Uenoyama Y, Mori Y, Steiner RA, Tsukamura H, et al. 2009 Gonadotrophin-releasing hormone pulse generator activity in the hypothalamus of the goat. Journal of Neuroendocrinology 21 813-821. (https://doi.org/10.1111/j.1365-2826.2009.01909.x)

Overgaard A, Ruiz-Pino F, Castellano JM, Tena-Sempere M \& Mikkelsen JD 2014 Disparate changes in kisspeptin and neurokinin B expression in the arcuate nucleus after sex steroid manipulation reveal differential regulation of the two KNDy peptides in rats. Endocrinology $\mathbf{1 5 5}$ 3945-3955. (https://doi.org/10.1210/en.2014-1200)

Polkowska J, Cieslak M, Wankowska M \& Wojcik-Gladysz A 2015 The effect of short fasting on the hypothalamic neuronal system of kisspeptin in peripubertal female lambs. Animal Reproduction Science 159 184-190. (https://doi.org/10.1016/j.anireprosci.2015.06.016)

Prasad BM, Conover CD, Sarkar DK, Rabii J \& Advis JP 1993 Feed restriction in prepubertal lambs: effect on puberty onset and on in vivo release of luteinizing-hormone-releasing hormone, neuropeptide $\mathrm{Y}$ and beta-endorphin from the posterior-lateral median eminence. Neuroendocrinology 57 1171-1181. (https://doi. org/10.1159/000126484)

Quennell JH, Mulligan AC, Tups A, Liu X, Phipps SJ, Kemp CJ, Herbison AE, Grattan DR \& Anderson GM 2009 Leptin indirectly regulates gonadotropin-releasing hormone neuronal function. Endocrinology 150 2805-2812. (https://doi.org/10.1210/en.2008-1693)

Ramaswamy S, Seminara SB, Ali B, Ciofi P, Amin NA \& Plant TM 2010 Neurokinin B stimulates GnRH release in the male monkey (Macaca mulatta) and is colocalized with kisspeptin in the arcuate nucleus. Endocrinology 151 4494-4503. (https://doi.org/10.1210/en.2010-0223)

Seminara SB, Messager S, Chatzidaki EE, Thresher RR, Acierno Jr JS, Shagoury JK, Bo-Abbas Y, Kuohung W, Schwinof KM, Hendrick AG, et al. 2003 The GPR54 gene as a regulator of puberty. New England Journal of Medicine 349 1614-1627. (https://doi.org/10.1056/ NEJMoa035322)

Shahab M, Mastronardi C, Seminara SB, Crowley WF, Ojeda SR \& Plant TM 2005 Increased hypothalamic GPR54 signaling: a potential mechanism for initiation of puberty in primates. PNAS $\mathbf{1 0 2}$ 2129-2134. (https://doi.org/10.1073/pnas.0409822102)

Shoham S, Marcus EL, Avraham Y \& Berry EM 2000 Diet restriction increases enkephalin- and dynorphin-like immunoreactivity in rat brain and attenuates long-term retention of passive avoidance.
Nutritional Neuroscience 3 41-55. (https://doi.org/10.1080/10284 15X.2000.11747302)

Smith JT, Acohido BV, Clifton DK \& Steiner RA 2006 KiSS-1 neurones are direct targets for leptin in the ob/ob mouse. Journal of Neuroendocrinology 18 298-303. (https://doi.org/10.1111/j.13652826.2006.01417.x)

Smith JT, Li Q, Yap KS, Shahab M, Roseweir AK, Millar RP \& Clarke IJ 2011 Kisspeptin is essential for the full preovulatory LH surge and stimulates GnRH release from the isolated ovine median eminence. Endocrinology 152 1001-1012. (https://doi.org/10.1210/en.2010-1225)

Thorson JF, Prezotto LD, Adams H, Petersen SL, Clapper JA, Wright EC, Oliver WT, Freking BA, Foote AP, Berry ED, et al. 2018 Energy balance affects pulsatile secretion of luteinizing hormone from the adenohypophesis and expression of neurokinin B in the hypothalamus of ovariectomized gilts. Biology of Reproduction 99 433-445. (https://doi.org/10.1093/biolre/ioy069)

Topaloglu AK, Reimann F, Guclu M, Yalin AS, Kotan LD, Porter KM, Serin A, Mungan NO, Cook JR, Imamoglu S, et al. 2009 TAC3 and TACR3 mutations in familial hypogonadotropic hypogonadism reveal a key role for neurokinin B in the central control of reproduction. Nature Genetics 41 354-358. (https://doi.org/10.1038/ ng.306)

Topaloglu AK, Tello JA, Kotan LD, Ozbek MN, Yilmaz MB, Erdogan S, Gurbuz F, Temiz F, Millar RP \& Yuksel B 2012 Inactivating KISS1 mutation and hypogonadotropic hypogonadism. New England Journal of Medicine 366 629-635. (https://doi.org/10.1056/ NEJMoa1111184)

True C, Kirigiti MA, Kievit P, Grove KL \& Smith MS 2011 Leptin is not the critical signal for kisspeptin or luteinising hormone restoration during exit from negative energy balance. Journal of Neuroendocrinology 23 1099-1112. (https://doi.org/10.1111/j.13652826.2011.02144.x)

Wakabayashi Y, Nakada T, Murata K, Ohkura S, Mogi K, Navarro VM, Clifton DK, Mori Y, Tsukamura H, Maeda K, et al. 2010 Neurokinin $\mathrm{B}$ and dynorphin $\mathrm{A}$ in kisspeptin neurons of the arcuate nucleus participate in generation of periodic oscillation of neural activity driving pulsatile gonadotropin-releasing hormone secretion in the goat. Journal of Neuroscience 30 3124-3132. (https://doi.org/10.1523/ JNEUROSCI.5848-09.2010)

Wang J, Zhou H, Zhang T, Sun L, Xu J \& Lou Y 2012 Evidence for a role of KISS-1/GPR54 system in decreased luteinizing hormone (LH) secretion in fasted prepubertal ewes. African Journal of Biotechnology 11 687-693.

Weems PW, Witty CF, Amstalden M, Coolen LM, Goodman RL \& Lehman MN 2016 kappa-opioid receptor is colocalized in GnRH and KNDy cells in the female ovine and rat brain. Endocrinology $\mathbf{1 5 7}$ 2367-2379. (https://doi.org/10.1210/en.2015-1763)

Weems PW, Coolen LM, Hileman SM, Hardy S, Mccosh RB, Goodman RL \& Lehman MN 2018 Evidence that dynorphin acts Upon KNDy and GnRH neurons during GnRH pulse termination in the ewe. Endocrinology 159 3187-3199. (https://doi.org/10.1210/en.201800435)

Whisnant CS \& Goodman RL 1988 Effects of an opioid antagonist on pulsatile luteinizing hormone secretion in the ewe vary with changes in steroid negative feedback. Biology of Reproduction 39 1032-1038. (https://doi.org/10.1095/biolreprod39.5.1032)

Yang JA, Yasrebi A, Snyder M \& Roepke TA 2016 The interaction of fasting, caloric restriction, and diet-induced obesity with 17 betaestradiol on the expression of KNDy neuropeptides and their receptors in the female mouse. Molecular and Cellular Endocrinology 437 35-50. (https://doi.org/10.1016/j.mce.2016.08.008)

Received in final form 19 September 2020

Accepted 1 October 2020

Accepted Manuscript published online 1 October 2020 https://raf.bioscientifica.com

https://doi.org/10.1530/RAF-20-0025 (c) 2020 The authors Published by Bioscientifica Ltd

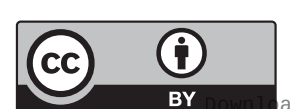

This work is licensed under a Creative Commons Attribution 4.0 International License. 